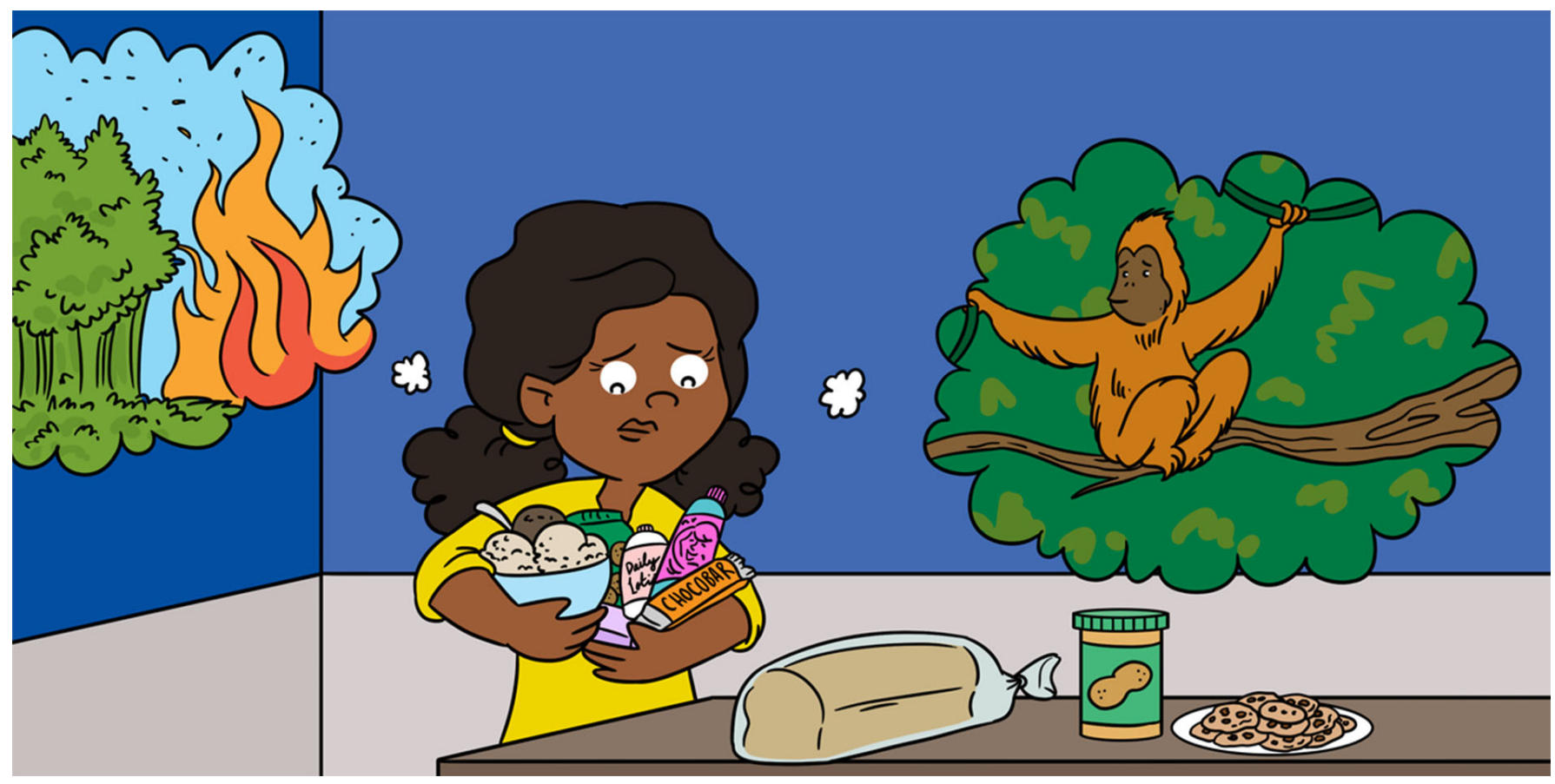

\title{
CAN PALM OIL BE PRODUCED WITHOUT AFFECTING BIODIVERSITY?
}

\section{Kirstie A. Goggin * and Denis J. Murphy}

Faculty of Computing, Engineering and Science, University of South Wales, Pontypridd, United Kingdom

\section{YOUNG REVIEWERS:}

CENTRO EDUCACIONAL SESI 242

AGE: 10

LAUREL

AGE: 8
Have you ever used or eaten palm oil? You might not think so, but odds are, you have. Palm oil is an ingredient in around half of supermarket products. It is used in ice cream, to help it melt nicely on your tongue, in the soap that you use to clean your dishes, and in most cakes, biscuits, and chocolate. Sounds useful, so what is the problem? Palm oil production is believed to account for up to half of the deforestation in tropical rainforests, leading to loss of biodiversity and many other negative impacts. Furthermore, palm oil production requires fertilizers and pesticides, which can run off into waterways and affect downstream biodiversity. However, most scientists agree that if we boycott palm oil and use other vegetable oils, the environmental impacts may be even worse. This article will discuss the pros and cons of palm oil production and how scientists, industries, and environmental organizations are trying to make palm oil more environmentally friendly. 
Figure 1

An oil palm growing in a plantation. Near the base of the trunk, you can see a fruit bunch that contains

thousands of individual palm fruits, from which palm oil is extracted.

Figure 2

(A) Palm fruit structure The mesocarp is the part that palm oil is extracted from and the endosperm is the part that palm kernel oil is extracted from.

(B) Palm oil at room temperature in the UK. It is orange due to its high vitamin content. (C) Palm kernel oil at room temperature in the UK. It has a lower vitamin content than palm oil, hence its yellow color.

\section{TROPICS}

The region of the Earth surrounding the equator, includes Malaysia, Indonesia, Colombia, Ecuador, Thailand, etc.

\section{MESOCARP}

The soft middle part of a fruit, between the outer skin and seed or kernel.

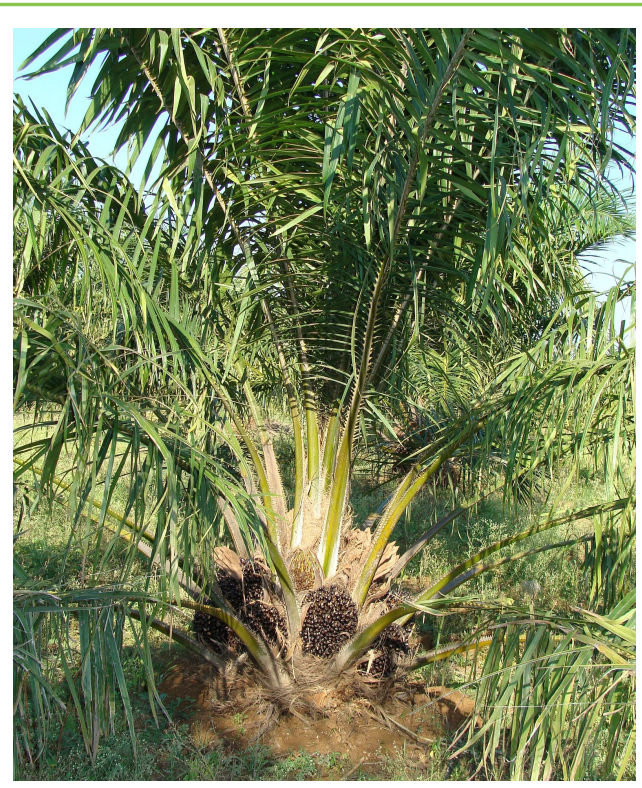

Figure 1

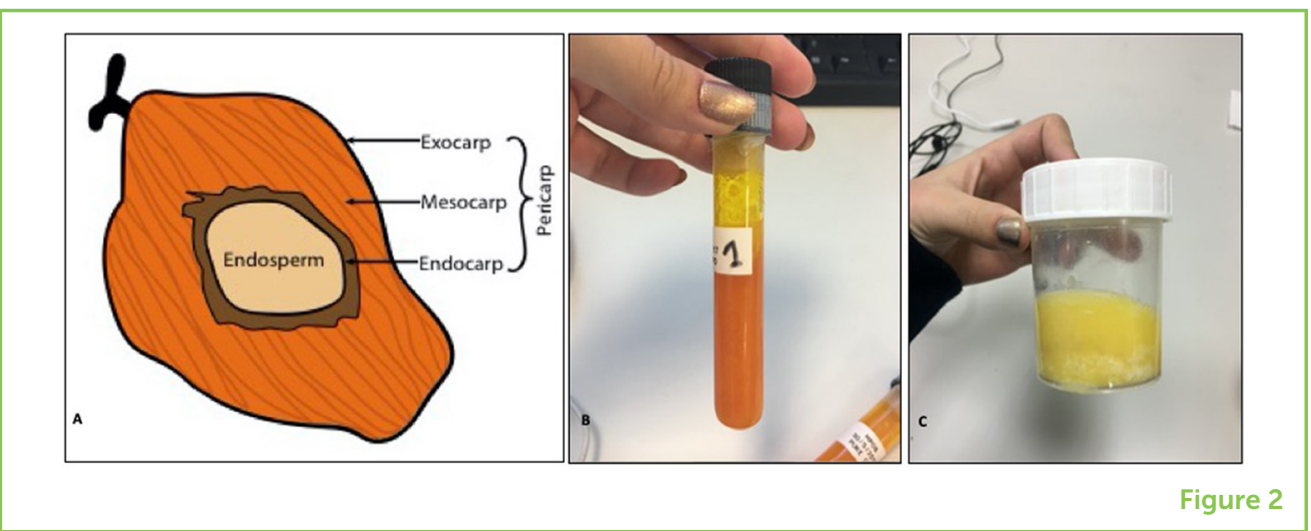

\section{WHAT IS PALM OIL AND WHERE DOES IT COME FROM?}

Palm oil is a vegetable oil extracted from the fruits of the oil palm plant, Elaeis guineensis (Figure 1). Oil palm is grown in the tropics, including Indonesia, Malaysia, and Thailand, and accounts for almost $40 \%$ of all vegetable oils produced around the world. Oil palm fruits are structured like plums. There is a hard, central nut (also known as a kernel) surrounded by a soft, fleshy layer called the mesocarp. The fruits are heated and crushed to obtain two types of useful oil: palm oil from the mesocarp and palm kernel oil from the kernel.

The chemical make-up of the two palm oils differs from other vegetable oils like olive oil and sunflower oil. In temperate countries, palm oils are solid at room temperature (Figure 2), making palm oil an ideal ingredient in pastries, cakes, biscuits, and ice cream. Palm kernel oil is mainly used as the active ingredient in cleaning products like soaps and detergents, as well as in cosmetics. 


\section{DEFORESTATION}

The action of clearing a large area of trees.

\section{SUSTAINABLE}

The quality of not being harmful to the environment, natural resources, or communities.

\section{BIODIVERSITY}

The variety of plant and animal life in the world or in a particular habitat, a high level of which is usually considered to be important and desirable.

SLASH-AND-BURN

The process of chopping down trees and plants and setting the land on fire to clear it for farming.

\section{WHAT IS SO BAD ABOUT PALM OIL?}

Unfortunately, like many other big crops, growing a lot of oil palms causes some problems! Historically, oil palm was often grown in areas with lots of different species. Malaysian rainforests have more than 2,000 species of trees, Asian and pygmy elephants, and Malayan tapirs. Indonesian rainforests contain endangered animals like Sumatran tigers and rhinos. Large areas of rainforests have been converted into oil palm plantations. Planting of oil palms accounts for $0.5 \%$ of deforestation globally. In areas where oil palm is grown, these crops can be responsible for up to $50 \%$ of the deforestation [1].

Laws have been set to limit the amount of forested areas that can be removed. For example, Malaysia has laws, such as the "Protection of Wildlife Act 1972" and the "Land Conservation Act 1960" to protect species and reduce impacts on the environment. Also, growers who are members of an organization called the Roundtable on Sustainable Palm Oil (RSPO) or Malaysian Sustainable Palm Oil (MSPO) are not allowed to clear forests or areas that contain high amounts of biodiversity or fragile ecosystems.

In some cases, illegal logging (chopping down trees) and a method of clearing land called slash-and-burn still take place. Slash-and-burn is the process where forests are logged and then set on fire. Clearing land with fire costs around US \$5 per hectare ( 1 hectare $=2$ football pitches). Clearing land legally, using machines and chemicals, costs around US \$200 per hectare. As you can imagine, slash-and-burn clearing is really bad for both the environment and the local people, because it results in huge emissions of toxic ash and smoke. When large forest areas are removed by slash-and-burn, something called haze happens. Haze is when the smoke fills the sky and blocks out sunlight. Haze can last for weeks and affect human health.

The most well-known issue of the oil palm industry is its effects on orangutan populations. Orangutans often lose their homes during land clearance and are sometimes killed by farmers who see them as pests. Some reports say that 25 orangutans are killed every day due to palm oil production. But, in reality, over half of all orangutan deaths are caused by local people who hunt orangutans for food [2].

\section{CAN WE JUST USE DIFFERENT OILS INSTEAD OF PALM?}

So, if growing oil palms causes such big problems, why cannot we just use other vegetable oils instead? The main issue here is that oil palm is a very efficient crop compared to alternatives like sunflower and olive. Nearly 10 times more land would be needed if oil palm were replaced with olive, soy, rapeseed (also known as canola), or corn crops [3]. Also, production of other vegetable oils would still impact biodiversity because those crops would need land to be cleared, too. 
Other oil crops are also more expensive to grow than palm. Olive oil production costs up to six times more than palm oil. If we were to try to put olive oil in food products like pastries or biscuits, the prices of those foods would also increase! The chemical make-up of olive oil is also very different from palm oil. Olive oil is full of chemicals that give it a strong taste, smell, and color. Companies who use palm oil choose it because it can be processed to remove its color, taste, and smell. This means palm oil cannot be tasted in the final food product, but it still provides the fat needed as an ingredient in many foods. Olive oil also goes bad a lot faster than palm oil. This can make the food it is added to taste terrible!

Oil palm production does not need much energy input. Oil palm crops need less fertilizers and pesticides than other vegetable oil crops. This means fewer dangerous chemicals leak out into the environment. Oil palm crops also have a very long lifespan. A farmer can profit from selling the fruits for over 25 years. Oil palm fruits can be harvested regularly year-round. Therefore, these plantations employ people permanently and not just seasonally as they are with other vegetable oil crops. This improves the lives of palm oil farm employees.

\section{ARE THERE WAYS TO MAKE PALM OIL MORE ENVIRONMENTALLY FRIENDLY?}

Up to $85 \%$ of natural forest species are lost when rainforests are converted to oil palm plantations [4]. Scientists are trying to find new ways to improve palm oil production so that it has less impact on the environment. Growers are also taking action to improve their practices. For example, they are following strict rules to reduce the use of fertilizers and pesticides and selecting better seeds to produce more oil from the same area of land.

WILDLIFE

\section{CORRIDOR}

A strip of natural habitat connecting populations of wildlife otherwise separated by cultivated land, roads, etc.
Wildlife corridors can also help to make oil palm farming more environmentally friendly. These corridors are areas of conserved land or forests within or between plantations. Wildlife corridors help to support biodiversity and allow animals to move around. For example, Borneo elephants normally travel through oil palm plantations and eat the trunks of old oil palms - up to $150 \mathrm{~kg}$ per day! This causes the growers to dislike the elephants. So, the growers teamed up with WWF-Malaysia to make a wildlife corridor of 1,067 hectares, linking two forests. They hope this will provide a route for the elephants to travel through the plantations, with different types of food so the oil palms will be saved [5]. Wildlife corridors are not just important for large mammals. Corridors along rivers within oil palm plantations are very important for invertebrates, such as moths and dung beetles [6]. Often, the animals will spend most of their time in the corridors rather than in the oil palm plantations. Wildlife corridors would not stop all the negative impacts that farming has on local animals, but they will 
Figure 3

In the center, you can see the RSPO-certified sustainable palm oil logo. This is the logo you will see on products if the palm oil in them is sustainable. Other similar organizations, like ISPO and MSPO, also have their own logos, which you can see on either side of the RSPO logo.

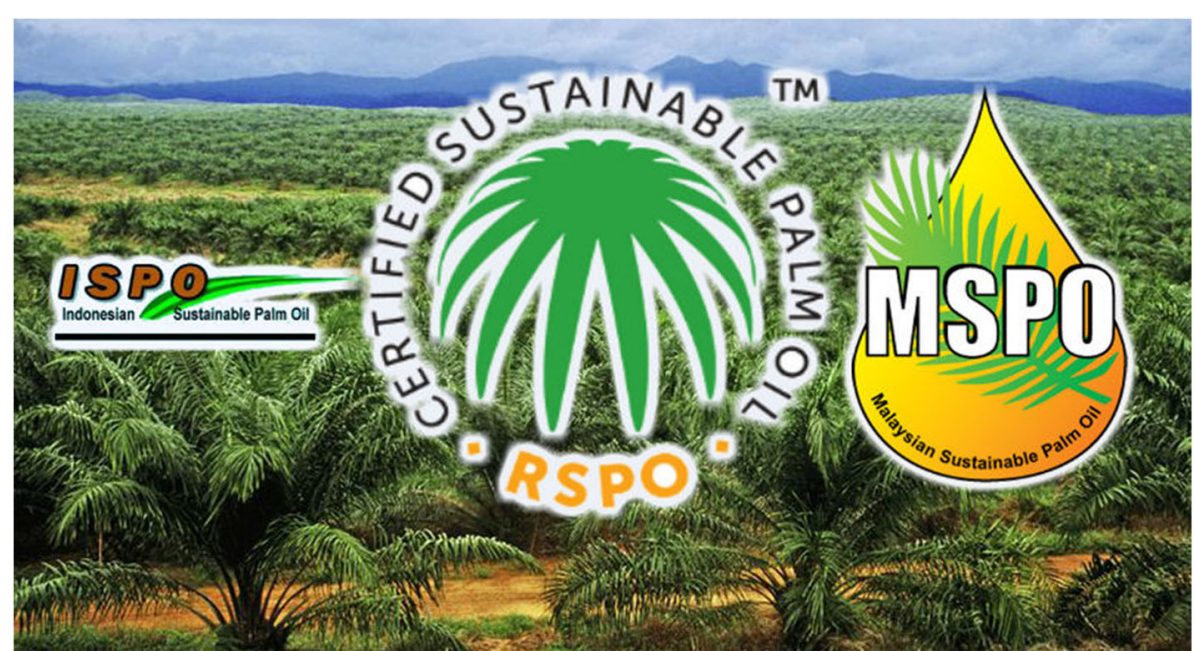

Figure 3

help animals move around better and provide different food sources, reducing conflict.

Other scientists found that some areas of wild forest should be kept within plantation areas. These areas of forest should be connected to each other by habitat corridors to maintain biodiversity. The good news is that this recommendation is now being used by big international companies like Unilever and organizations like RSPO.

Growing oil palm on unused farm land could also help to reduce deforestation [7]. Scientists have shown that turning unused farm land into oil palm plantations reduces carbon emissions by $99.7 \%$, compared to clearing rainforests for these farms. The amount of biodiversity on unused farm land is also much lower than that of rainforests, so biodiversity levels may actually increase if oil palms are planted on this unused land [8].

The RSPO is trying to improve the palm oil industry by helping oil palm plantations and biodiversity to co-exist. To become members of RSPO, palm oil production companies must follow seven rules:

1. Behave ethically and transparently

2. Operate legally

3. Optimize productivity, efficiency, and positive impacts

4. Respect community and human rights, and provide benefits to communities (such as playgrounds, childcare, and schools)

5. Support smallholder plantations (plantations usually owned by a single family)

6. Respect workers' rights and provide a good work environment

7. Protect, conserve, and improve ecosystems and the environment. 
If they stick to these rules, companies can use the RSPO logo (Figure $3)$, which proves that their palm oil has been produced sustainably. Other sustainable palm oil organizations operate similarly, including MSPO and Indonesian Sustainable Palm Oil (ISPO). They too have their own recognizable logos, which are used on products around the globe (Figure 3).

\section{SO, CAN PALM OIL BE PRODUCED WITHOUT AFFECTING BIODIVERSITY?}

In short, the answer is no. Production of palm oil will continue to impact biodiversity in the tropics. Scientists are working very hard to find new ways of reducing the environmental impact of this crop. However, it is unlikely that palm oil (or any other agricultural product) can be produced without impacting biodiversity in some way. However, scientists agree that we have the power to improve palm oil production and make it more sustainable. This will hopefully minimize the impacts of palm oil production on biodiversity.

\section{HOW CAN YOU HELP?}

If you want to help make sure palm oil is being produced sustainably, there are several things you could consider. You can become a wildlife hero simply by eating locally produced and wholesome (non-processed) foods. Not only is this healthier for you, but it is also healthier for the environment, because local products do not need to travel around the world before reaching your plate or lunchbox!

Also, if you find out that your favorite chocolate bar does not contain sustainable palm oil, then write a letter or an email to the company and explain to them how disappointed you are and what they could do to help. You could download Act for Wildlife's Sustainable Palm Oil shopping list (https://www.chesterzoo.org/what-you-can-do/ourcampaigns/sustainable-palm-oil/sustainable-palm-oil-shopping-list/) to find replacement foods. Maybe you even feel passionate enough to start a conversation with your friends, to find strategies to boycott products using non-sustainable palm oil. For example, you can ask your local supermarket to replace products using non-sustainable palm oil with other more environmentally friendly options. You and your friends can even help stores by making a list of those products. Last, you could help by learning even more about which companies are using sustainable palm oil or which products contain sustainable palm oil. Here are some resources:

- Visit https://rspo.org/members/all (Global)

- Visit https://www.agropalma.com.br (Brazil)

- Download the Giki app https://gikibadges.com (Global) 
- Download the Sustainable Palm Oil Shopping Guide https://play. google.com/store/apps/details?id=com.venturedna. palmoil\&hl= en (United States)

- Read https://www.greenpeace.org/archive-international/Global/ international/publications/forests/2016/gp_IND_PalmScorecard _FINAL.pdf (Global)

- Download the Palm Oil Scanner app https://apps.apple.com/au/ app/palm-oil-scanner/id1264641219 (Global)

Never forget that little actions lead to big changes! The sustainable palm oil movement is global, and YOU can be a part of it!

\section{REFERENCES}

1. Potapov, P., Hansen, M. C., Laestadius, L., Turubanova, S., Yaroshenko, A., Thies, C., et al. 2017. The last frontiers of wilderness: tracking loss of intact forest landscapes from 2000 to 2013. Sci. Adv. 3:e1600821. doi: 10.1126/sciadv.16 00821

2. Abram, N. K., Meijaard, E., Wells, J. A., Ancrenaz, M., Pellier, A., Runting, R. K., et al. 2015. Mapping perceptions of species' threats and population trends to inform conservation efforts: the Borenean orangutan case study. Divers. Distrib. 21:487-9. doi: 10.1111/ddi.12286

3. Meijaard, E., Garcia-Ulloa, J., Sheil, D., Wich, S. A., Carlson, K. M., Juffe-Bignoli, D., et al. 2018. Gland, IUCN. Oil Palm and Biodiversity. A Situation Analysis by the IUCN Oil Palm Task Force.

4. Danielsen, F., Beukema, H., Burgess, N. D., Parish, F., Donald, P. F., Murdiyarso, D., et al. 2008. Biofuel plantations on forested lands: double jeopardy for biodiversity and climate. Conserv. Biol. 23:348-58. doi: 10.1111/j.1523-1739.2008.01096.x

5. Cudmore, B. 2016. Designing the Ideal Wildlife Corridor for Malaysia's Orangutans. Mongabay. Available online at: https://news.mongabay.com/2016/ 04/designing-ideal-wildlife-corridor-malaysias-orangutans (accessed January 13, 2020).

6. Gray, R. E. J., Slade, E. M., Chung, A. Y. C., and Lewis, O. T. 2019. Movement of moths through riparian reserves within oil palm plantations. Front. For. Glob. Change 2:68. doi: 10.3389/ffgc.2019.00068

7. Murphy DJ. Oil palm: future challenges for a key global crop. In: Allan T, Bromwich B, Keulertz M, Colman A, editors. Oxford Handbook of Water, Food and Society. Oxford: Oxford University Press (2018).

8. Quezada, J. C., Etter, A., Ghazoul, J., Buttler, A., and Guillaume, T. 2019. Carbon neutral expansion of oil palm plantations in the neotropics. Sci. Adv. 5:eaaw4418. doi: 10.1126/sciadv.aaw4418

SUBMITTED: 13 January 2020; ACCEPTED: 29 May 2020; PUBLISHED ONLINE: 07 July 2020.

EDITED BY: Pedro Morais, University of Algarve, Portugal 

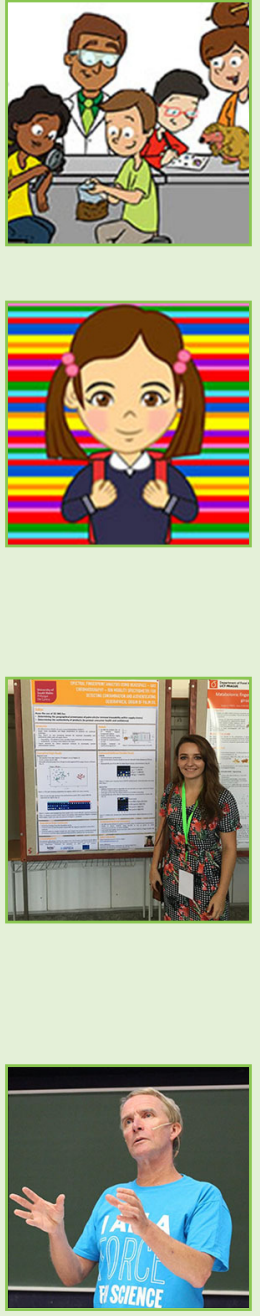

CITATION: Goggin KA and Murphy DJ (2020) Can Palm Oil Be Produced Without Affecting Biodiversity? Front. Young Minds 8:86. doi: 10.3389/frym.2020.00086

CONFLICT OF INTEREST: The authors declare that the research was conducted in the absence of any commercial or financial relationships that could be construed as a potential conflict of interest.

COPYRIGHT @ 2020 Goggin and Murphy. This is an open-access article distributed under the terms of the Creative Commons Attribution License (CC BY). The use, distribution or reproduction in other forums is permitted, provided the original author(s) and the copyright owner(s) are credited and that the original publication in this journal is cited, in accordance with accepted academic practice. No use, distribution or reproduction is permitted which does not comply with these terms.

\section{YOUNG REVIEWERS}

\section{CENTRO EDUCACIONAL SESI 242, AGE: 10}

We are 10 years old. We are happy, talkatives, and we love to play with each other.

\section{LAUREL, AGE: 8}

I love reading Harry Potter books. My favorite characters are Ginny and Hermione. I also like animals. My favorite subjects in school are art, music, science, and math.

\section{AUTHORS}

\section{KIRSTIE A. GOGGIN}

For the past 3 years, I have been studying the chemical composition of palm oil and how it relates to sustainability and where it was grown. I have developed ways of determining which country palm oil comes from, based on the compounds responsible for its smell. I love everything about nature and love going for long strolls with my dog to see which birds I can spot in their natural habitats. *kirstie.goggin@southwales.ac.uk

\section{DENIS J. MURPHY}

Prof. Murphy is a Fellow of the Royal Society of Biology and Professor of Biotechnology at the University of South Wales, UK. His research is mainly focused on improvement of oil crops using genomic and biotechnological methods. His group is also working on improved methods to verify the origin and purity of palm oils as part of the requirement for ensuring that such oils are obtained from certified sustainable sources. He is Biotechnology Advisor to the United Nations Food and Agriculture Organization and also advises the government-run Malaysian Palm Oil Board. 